\title{
Effect of Babao Dan on angiogenesis of gastric cancer in vitro by regulating VEGFA/VEGFR2 signaling pathway
}

\author{
Jian-Hua Guan $^{1 \#}$, Zhi-Yun Cao $^{1,2 \#}$, Bin Guan ${ }^{3 \#}$, Li-Hui Wei ${ }^{1,2}$, Jun Peng ${ }^{1,2}$, You-Qin Chen ${ }^{1,4}$, \\ Thomas Joseph Sferra, ${ }^{1,4}$, Senthilkumar Sankararaman ${ }^{1,4}$, Zhi-Xue Zhan ${ }^{3}$, Jiu-Mao Lin ${ }^{1,2}$ \\ ${ }^{1}$ Academy of Integrative Medicine of Fujian University of Traditional Chinese Medicine, Fuzhou, China; ${ }^{2}$ Fujian Key Laboratory of Integrative \\ Medicine on Geriatrics, Fujian University of Traditional Chinese Medicine, Fuzhou, China; ${ }^{3}$ Xiamen Traditional Chinese Medicine Co., Ltd., \\ Xiamen, China; ${ }^{4}$ Department of Pediatrics, Case Western Reserve University School of Medicine, Rainbow Babies and Children's Hospital, \\ Cleveland, OH, USA. \\ Contributions: (I) Conception and design: JM Lin; (II) Administrative support: J Peng; (III) Provision of study materials or patients: ZY Cao, B Guan; \\ (IV) Collection and assembly of data: JH Guan, ZY Cao; (V) Data analysis and interpretation: LH Wei, YQ Chen, TJ Sferra, S Sankararaman, ZX \\ Zhan; (VI) Manuscript writing: All authors; (VII) Final approval of manuscript: All authors. \\ \#These authors contributed equally to this work. \\ Correspondence to: Jiu-Mao Lin. Academy of Integrative Medicine of Fujian University of Traditional Chinese Medicine, 1 Qiuyang Road, Minhou \\ Shangjie, Fuzhou, Fujian 350122, China. Email: linjiumao@fjtcm.edu.cn.
}

Background: To further elucidate the anti-angiogenesis effect of Babao Dan (BBD) in vitro, gastric cancer (GC) cells and human umbilical vein endothelial cells (HUVECs) were used to evaluate the regulation role of BBD by vascular endothelial growth factor A (VEGFA)/vascular endothelial growth factor receptor 2 (VEGFR2) signaling pathway.

Methods: After induced by VEGFA, GC cells (AGS, MGC80-3 and BGC823) were treated by different concentrations of BBD and then were detected cell viability, migration and VEGFA level. And the antiangiogenesis effect of BBD was evaluated with HUVECs. To furtherly mimic the tumor microenvironment of angiogenesis, VEGFA as an inducer $(10 \mathrm{ng} / \mathrm{mL})$ was used to trigger a cascade of angiogenesis of HUVECs in vitro.

Results: The viability and migration of GC cells with VEGFA-induced or non-induced and VEGFA levels in GC cells were significantly inhibited by BBD with concentration-dependent manner $(\mathrm{P}<0.01)$. BBD significantly inhibited the HUVECs viability with concentration-dependent manner $(\mathrm{P}<0.01)$, which was consistent with the inhibitory action on augmentation of cell viability induced by VEGFA $(\mathrm{P}<0.01)$. BBD exhibited the similar inhibitory trend on cyto behavioral variability such as wound repairing $(\mathrm{P}<0.05)$, migration $(\mathrm{P}<0.01)$ and tube formation $(\mathrm{P}<0.01)$ and activation effect on cell apoptosis rate $(\mathrm{P}<0.01)$ with VEGFA-induced or non-induced. Moreover, BBD notably regulated the levels of VEGFA, VEGFR2, matrix metalloprotein 2 (MMP2) and matrix metalloprotein 9 (MMP9) of HUVECs on present or absent of VEGFA with dose-dependent manner.

Conclusions: BBD inhibited GC growth against VEGFA-induced angiogenesis of HUVECs by VEGFA/ VEGFR2 signaling pathway in vitro.

Keywords: Babao Dan (BBD); gastric cancer (GC); angiogenesis; human umbilical vein endothelial cells (HUVECs); vascular endothelial growth factor A (VEGFA); vascular endothelial growth factor receptor 2 (VEGFR2)

Submitted Jul 19, 2020. Accepted for publication Dec 04, 2020.

doi: $10.21037 /$ tcr-20-2559

View this article at: http://dx.doi.org/10.21037/tcr-20-2559 


\section{Introduction}

Gastric cancer (GC) is one of the most common digestive tract neoplasms which are seriously threatening human health. At present, there is a high incidence of GC in China which accounts for approximately $50 \%$ of the world's GC morbidity (1).

Currently, major clinical treatments of GC include surgery, radiotherapy and chemotherapy. Surgery was the preferred option for early stage patients while most patients who were diagnosed already at middle or advanced stage have to give up surgery for multi-metastasis. Radiotherapy and chemotherapy are usually used to treat patients at perioperative period but the toxicity of common drugs often cause serious side effects and resistance which have extensively limited their clinical application (2). Therefore, there is a strong demand on finding some new drugs of low side-effect and no-drug-resistance for GC treatment. Accumulating attention has been paid for tumor angiogenesis field because it is a key factor in the occurrence, development and metastasis of GC. Currently, the application of angiogenesis is mainly to evaluate the malignant degree and poor prognosis of various cancers. In future as might be expected, its importance in tumor growth and metabolization would make it become a very effective strategy for clinical treatment with the developing study (3). Angiogenesis is a key factor for tumor to obtain nutrients and metabolize which further leads to tumor metastasis. In the absence of blood vessels, tumor volume is hardly larger than $2 \mathrm{~mm}$ in diameter. When tumor volume is larger than that, it is necessary to arise new blood vessels for providing more nutrients and $\mathrm{O}_{2}$ for tumor growth and metastasis (4). Vascularization in vivo requires a series of step including proangiogenic factors releasing from tumor cells such as vascular endothelial growth factors (VEGFs, including VEGFA, VEGFB, VEGFC and VEGFD), vascular endothelial growth factor receptors (VEGFRs, including VEGFR1, VEGFR2 and VEGFR3), angiopoietin et al., the activated endothelial cells by stimulator factors beginning to release proteases, these proteases degrading the basement membrane to allow endothelial cells to spread and proliferate into the surrounding matrix to build the new vessels. Among proangiogenic factors, VEGFA is the violent mediator of vasculogenesis by binding its specific receptor VEGFR2 to activate the signaling pathway of angiogenesis (5). VEGF-A is an angiogenic factor produced by tumor cells which induces the growth of endothelial cells and leads to form the new blood vessels. VEGFR-2 is the receptor of
VEGF-A which expressing on endothelial cells can bind with VEGFA and then initiate angiogenesis (6), including endothelial cell survival, proliferation, invasion, migration, tube formation and sprouting, etc. $(7,8)$.

Babao Dan (BBD), a famous traditional Chinese medicine (TCM) formula, mainly compose of Calculus Bovis, Saigae Tataricae Cornu, Moschus, Notoginseng Radix Et Rhizoma, Margarita, Snake Gall, which has been widely used as a complementary and alternative medicine to treat many kinds of malignant tumor including primary liver cancer, bladder carcinoma, lung cancer and so on. Clearing heat and removing dampness, hemostasis and relieving pain are all its clinical efficacy according to the theory of TCM (9). The effect of BBD is significant on reducing the complications of interventional treatment, protecting liver function which attenuated hepatic fibrosis and ameliorated liver injury (10), improving treatment compliance, prolonging patient survival time (11). From above it is obvious that BBD has a curative effect in adjuvant treatment of hepatocellular carcinoma (12). And some basic research partly illustrated the anti-tumor mechanism of $\mathrm{BBD}$ on inhibiting the proliferation and promoting the apoptosis of tumor cells (13). By reducing the expression of antiapoptosis-related genes $\mathrm{Bcl}-2$ and survivin, increasing the level of proapoptosis gene Bax, BBD promoted the apoptosis of osteosarcoma cells U-2OS (14). Our previous studies have found that BBD induced GC cells apoptosis via regulating MAPK and $N F-\kappa B$ signaling pathways (15), and inhibited the migration and invasion of GC cells by suppressing epithelial-mesenchymal transition through the TGF- $\beta /$ Smad pathway (16). However, it is unclear about the effect of BBD on inhibiting angiogenesis of GC. In this study, we detected the molecular mechanism of BBD on anti-angiogenesis effect in vitro.

We present the following study in accordance with the MDAR checklist (available at http://dx.doi.org/10.21037/ tcr-20-2559).

\section{Methods}

\section{Reagents}

RPMI-1640 Medium 1640 basic (1×) (Gibco by Thermo Fisher Scientific TM, Cat No: C11875500BT), PenicillinStreptomycin Solution (HyClone, South Logan, UT, USA. Cat No: SV30010), In vitro Angiogenesis Assay Kit (Germany Millipore, Billerica, MA, USA. Cat No: ECM625), Fetal Bovine Serum (FBS, Capricorn scientific, 
Australia, Cat No: FBS-52A), 0.25\% Trypsin-EDTA (Gibco by Life Technologies. Cat No: 25200072), Phosphate Buffered Saline (PBS, HyClone, South Logan, UT, USA. Cat No: SH30256.01), Transwell ${ }^{\circledR}$ Permeable Supports, $6.5 \mathrm{~mm}$ Insert, 24 well plate. $8.0 \mu \mathrm{m}$ polycarbonate Membrance. Tissue Culuture Tramed polystyrene (CORNING. Cat No: 113), VEGFA (GenScript. Cat No: Z02689-10.), $\beta$ actin Mouse Monoclonal antibody (Proteintech. Cat No: 66009-1-lg), VEGFA Rabbit Polyclonal antibody (Cat No: 66828-1-Ig), VEGFR2 Rabbit Polyclonal antibody (Proteintech. Cat No: 264151-AP), MMP2 Rabbit Polyclonal antibody (Proteintech. Cat No: 10373-2-AP), MMP9 Rabbit Polyclonal antibody (Proteintech. Cat No: 10375-2-AP), HRP-conjugated Affinipure Goat Anti-Mouse $\operatorname{IgG}(\mathrm{H}+\mathrm{L})$ (Proteintech. Cat No: SA00001-1), HRP-conjugated Affinipure Goat AntiRabbit IgG (H+L) (Proteintech. Cat No: SA00001-2), Super ECL Star (US EVERBRIGHT. INC, Cat No: S6010-A-100 mL; S6010-B-100 mL), BBD (Xiamen traditional Chinese medicine Co., Ltd. Lot: 150930).

\section{Cell culture}

Human umbilical vein endothelial cells (HUVECs) were purchased from Cell Center of Xiangya School of Medicine, Central South University (Changsha, China). Human GC cell lines AGS, MGC80-3 and BGC823 were donated from Fujian Normal University Biomedical Research Center of South China (Fuzhou, China). HUVECs and the human GC cell lines were cultured in RPMI-1640. RPMI-1640 was supplemented with $10 \%(\mathrm{v} / \mathrm{v}) \mathrm{FBS}, 100 \mathrm{U} / \mathrm{mL}$ penicillin and $100 \mu \mathrm{g} / \mathrm{mL}$ streptomycin in $5 \% \mathrm{CO}_{2}$ at $37{ }^{\circ} \mathrm{C}$. The representative images of GC cells and HUVECs without treated were shown in the Figure S1 (100x).

\section{Cell viability assay}

GC cell lines (AGS, MGC80-3, BGC823) and HUVECs were seeded into 96-well plates for $12 \mathrm{~h}$ and then treated by different concentration of BBD (GC cells: 0, 0.25, 0.5, 0.75, 1, 1.5, 2 and $4 \mathrm{mg} / \mathrm{mL}$, HUVECs: $0,0.25,0.5,0.75,1,1.5$ and $2 \mathrm{mg} / \mathrm{mL}$ ) or addition $10 \mathrm{ng} / \mathrm{mL}$ VEGFA were added to treat cells. These concentrations in this draft were also used in our team published papers. After $24 \mathrm{~h}$ of incubation in the constant temperature incubator $\left(5 \% \mathrm{CO}_{2}, 37{ }^{\circ} \mathrm{C}\right)$, 3-(4,5-dimethylthiazol-2-yl)-2,5-diphenyltetrazolium bromide (MTT, Sigma, Darmstadt, Germany) was added to each well $(0.5 \mathrm{mg} / \mathrm{mL}, 100 \mu \mathrm{L} /$ well $)$ for $4 \mathrm{~h}$, after that
MTT was sucked away. Then $100 \mu \mathrm{L}$ dimethyl sulfoxide was added to dissolve the formazan precipitate of MTT. At last, the absorbance at $570 \mathrm{~nm}$ was measured by ELISA plate reader (EXL800, BioTek Instruments, Winooski, VT, USA). Cell viability was calculated on the basis of the following formula: cell viability $(\%)=$ average absorbance of BBD group/average absorbance of control group $\times 100 \%$.

\section{Cell morphology observation}

The logarithmic phase of HUVECs $\left(2 \times 10^{5}\right.$ cells $\left./ \mathrm{mL}\right)$ were seeded in 6-well plates. After cells were treated with different concentrations of BBD or additional $10 \mathrm{ng} / \mathrm{mL}$ VEGFA for $24 \mathrm{~h}$, morphological character was observed and photographed by inverted microscope (DMIL LED, Leica, Wetzlar, Germany) (200x).

\section{Hoechst assay}

The logarithmic phase of HUVECs $\left(1 \times 10^{5}\right.$ cells $\left./ \mathrm{mL}\right)$ were seeded in 12-well plates. When cells convergence degree reached $50-60 \%$, different concentrations of BBD $(0,0.25,0.5,0.75 \mathrm{mg} / \mathrm{mL})$ or addition $10 \mathrm{ng} / \mathrm{mL}$ VEGFA were added to treat cells for $24 \mathrm{~h}$. Then abandon the original medium and clean cells with PBS $(0.5 \mathrm{~mL} /$ well), subsequently fix cell with $4 \%$ paraformaldehyde solution for 10 minutes. At last cells were stained with Hoechst for 10 minutes and then photographed by fluorescent microscope (DMI4000B, Leica, Wetzlar, Germany) $(100 \times)$. Apoptotic cells showed heavy fluorescence with Hoechst33258 staining.

\section{Wound bealing assay}

The logarithmic phase of HUVECs $\left(3 \times 10^{5}\right.$ cells $\left./ \mathrm{mL}\right)$ were seed in 6-well plates. When convergence degree reached $80 \sim 90 \%$ for scratches, suck out the original medium and then clean three times with $1 \mathrm{~mL}$ PBS. Abandon the PBS and add nutrient solution culture containing different concentrations of BBD $(0,0.25,0.5,0.75 \mathrm{mg} / \mathrm{mL})$ or additional $10 \mathrm{ng} / \mathrm{mL}$ VEGFA into each well respectively. Microscope taking photos at $0,6,12$, and 24 h by using inverted microscope (DMIL LED, Leica, Wetzlar, Germany) (100×).

\section{Transwell migration analysis}

The logarithmic phase of GC cell lines (AGS, MGC80- 
3, BGC823) and HUVECs were treated by different concentration of BBD $(0,0.25,0.5,0.75 \mathrm{mg} / \mathrm{mL})$ or additional $10 \mathrm{ng} / \mathrm{mL}$ VEGFA for $24 \mathrm{~h}$, the drug-containing medium was abandoned, and cells were digested. $200 \mu \mathrm{L}$ cell suspension $\left(2.5 \times 10^{5}\right.$ cells $\left./ \mathrm{mL}\right)$ was added into small indoor, and $700 \mu \mathrm{L}$ complete medium into outdoor. The plate was cultured in constant temperature incubator for $12 \mathrm{~h}$ (except BGC823 for $24 \mathrm{~h}$ ) at $37^{\circ} \mathrm{C}$, gently wipe small interior ministry indoor with dry cotton swab and then fastened with $4 \%$ paraformaldehyde, stained with crystal violet following to observe by inverted microscope (DMIL LED, Leica, Wetzlar, Germany) lens randomly selecting five view photos $(100 \mathrm{x})$.

\section{Tube formation assay}

HUVECs $\left(4 \times 10^{4}\right.$ cells/well) which pretreated by BBD or additional $10 \mathrm{ng} / \mathrm{mL}$ VEGFA as inducer were seeded into 48-well plates which added in Matrigel with growth factor for $3 \mathrm{~h}$ at $37^{\circ} \mathrm{C}$. Images were captured with an inverted microscope (DMIL LED, Leica, Wetzlar, Germany). The structure of the lumen is evaluated by the rate of formation in the tube. Tube sprouting rate $(\%)=($ sprouted cells/total cells) $\times 100$.

\section{Western blot}

The VEGFA or VEGFR2 protein levels of human GC cell lines (AGS, MGC80-3, BGC823) or HUVECs were detected by western blot analysis, respectively. Cells were cultured in $25 \mathrm{~cm}^{2}$ flasks at a constant density of $1.0 \times 10^{5}$ cells $/ \mathrm{mL}$ and treated with different concentrations of $\operatorname{BBD}(0,0.25$, 0.5 and $0.75 \mathrm{mg} / \mathrm{mL}$ ) for $24 \mathrm{~h}$. After cells were all lysed by radio immunoprecipitation assay cell lysis buffer and extracted the total protein, the protein concentration of each sample was quantified by bicinchoninic acid assay. Equal amounts of protein $(50 \mu \mathrm{g})$ were as electrophoretic sample to separate the target protein on $10 \%$ SDS PAGE gel and then transferred onto nitrocellulose filter membranes. Blocked the membrane for $2 \mathrm{~h}$ at room temperature, then incubated with VEGFA $(1: 3,000)$, VEGFR2 (1:1,000), MMP2 (1:1,000), MMP9 $(1: 1,000)$ and $\beta$-actin $(1: 5,000)$ at $4{ }^{\circ} \mathrm{C}$ for $14-18 \mathrm{~h}$. Washing 3 times each for $0.5 \mathrm{~h}$ at room temperature, and then incubated with horseradish peroxidase conjugated secondary antibodies $(1: 5,000)$ at room temperature for $2 \mathrm{~h}$, protein bands were photographed with Super ECL Star and analyzed by Image $\mathrm{Lab}^{\mathrm{TM}}$ software (version 3.0; Beyotime Institute of
Biotechnology, CA, USA).

\section{Statistical analysis}

Results should be implemented at least 3 independent repetitions. In this manuscript, all the quantitative data was shown as means \pm standard deviation (SD). Data were analyzed via SPSS 22.0 software and performed with one-way analysis of Variance if accorded with normal distribution, Single factor analysis of variance (ANOVA) was used among multiple groups. If not normal distribution, data were performed with K Independent Samples. $\mathrm{P}<0.05$ represented the statistical significance.

\section{Results}

\section{BBD inbibited VEGFA expression and reversed the viability and migration induced by VEGFA of GC cells}

To evaluate the effect of BBD on the growth of GC cells, different concentration BBD as indicated was treated to GC cells and then cells viability was determined by MTT assay following treatment for $24 \mathrm{~h}$ (Figure 1A). The results showed that BBD significantly inhibited the gastric cells growth and reduced the cell viability on dose-dependent manner compared to untreated control cells.

And the VEGFA protein level was further detected for confirming the probably reason of cell viability reducing. The results indicated that the level of VEGFA was downregulated with a dose-dependent manner as the cell viability continuously declined after treated by BBD (Figure 1B,C).

Furthermore, the viability and migration of GC cells induced by VEGFA also was detected. The results showed that VEGFA stimulated GC cells growth and migration in which was reversed by BBD with a dose dependent manner (Figure 1D,E,F).

\section{BBD inhibited angiogenesis of HUVECs}

Next the effect of BBD on HUVECs viability and apoptosis was determined by MTT and Hoechst 33258. After treated by different concentration of BBD for $24 \mathrm{~h}$, the cells viability significantly steady reduction in a dose-dependent manner (Figure 2A). Following the apoptosis of HUVECs showed that the BBD markedly induced the cells apoptosis in a dosage-dependent manner (Figure 2B,C), and the apoptotic cells are marked with arrowhead.

And then the damage repair ability and migration ability 

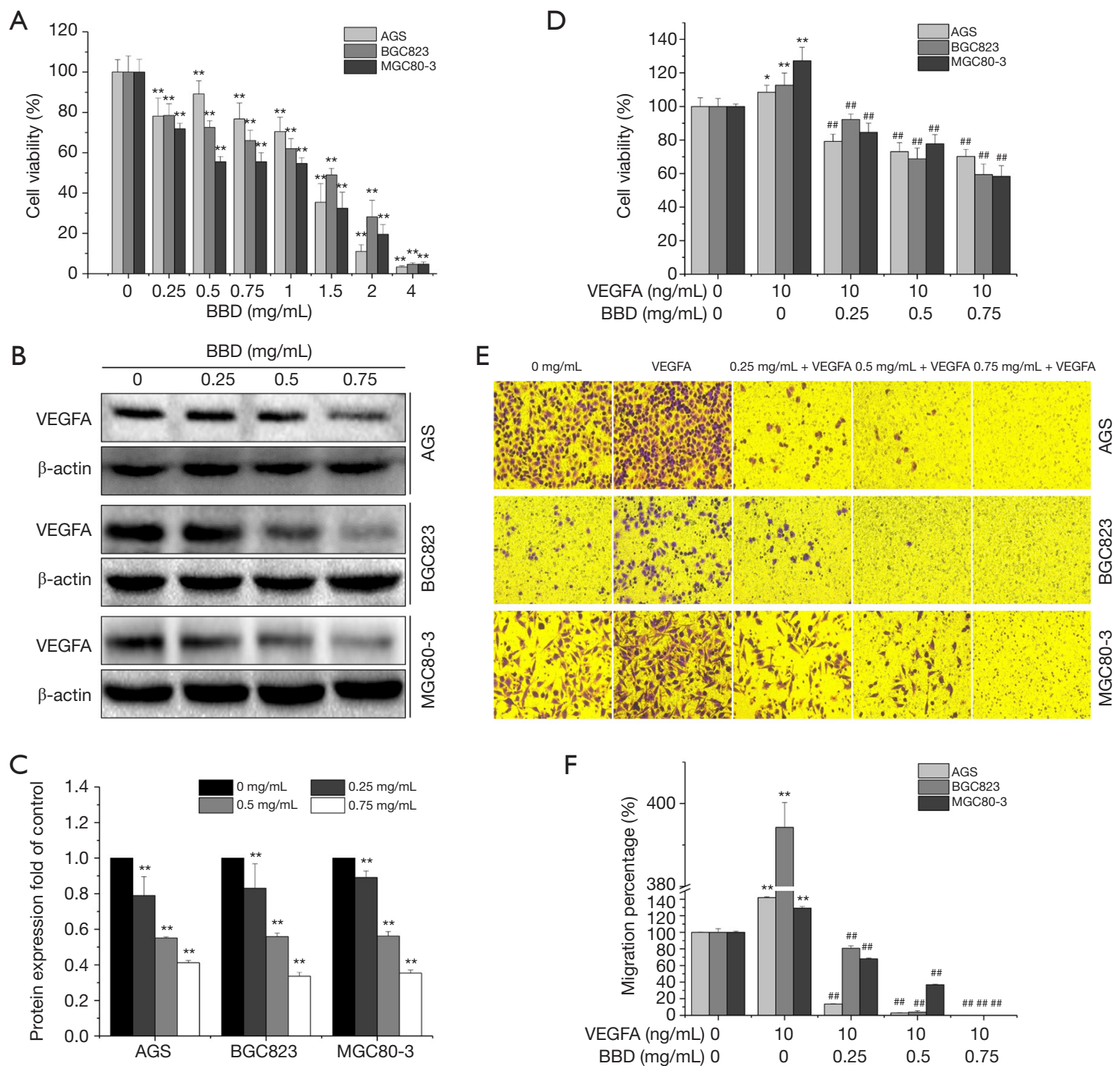

Figure 1 BBD inhibited VEGFA expression and reversed the viability and migration induced by VEGFA of GC cells. (A) GC cells were incubated at different concentrations of BBD for $24 \mathrm{~h}$ and then cell viability was assayed by MTT. (B,C) VEGFA level of different GC cell lines treated by BBD for $24 \mathrm{~h}$ was analysed by western blot. (D) BBD reversed the viability of GC cells induced by VEGFA for $24 \mathrm{~h}$. (E,F) BBD reversed the migration of GC cells induced by VEGFA. Data were shown as means \pm SD of three independent experiments. * $\mathrm{P}<0.05$ and ${ }^{* *}, \mathrm{P}<0.01$ versus control $(0 \mathrm{mg} / \mathrm{mL}),{ }^{\#}, \mathrm{P}<0.05$ and ${ }^{\# \#}, \mathrm{P}<0.01$ versus VEGFA.

of HUVECs after BBD treated were further observed. As shown in the Figure 3, Figure 3A,D and Figure 3B,E, BBD significantly inhibited the direct repair and migration of HUVEC cells. And in the Figure 3C,F, BBD significantly inhibited HUVECs tube formation.

Last, as shown in the Figure $4 A, B$, the protein expressions of VEGFA, VEGFR2, MMP2, MMP9 were suppressed by BBD at different degrees.

\section{BBD suppressed VEGF-induced angiogenesis of HUVECs}

To further determine the effect of BBD on VEGF-induced HUVECs growth, the MTT assay was firstly used to evaluate the cell viability. As showed in the Figure $5 A, B$, BBD inhibited the growth of HUVECs induced by VEGFA in a dose-dependent manner after $24 \mathrm{~h}$ treated compared with untreated controls cells. 


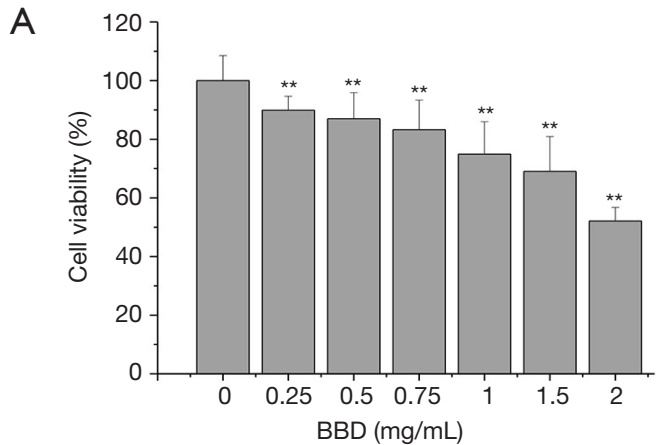

B

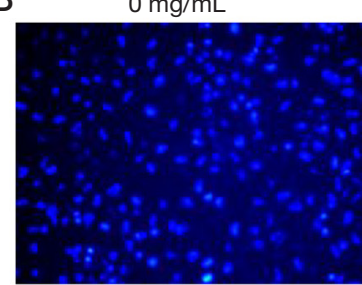

$0.5 \mathrm{mg} / \mathrm{mL}$
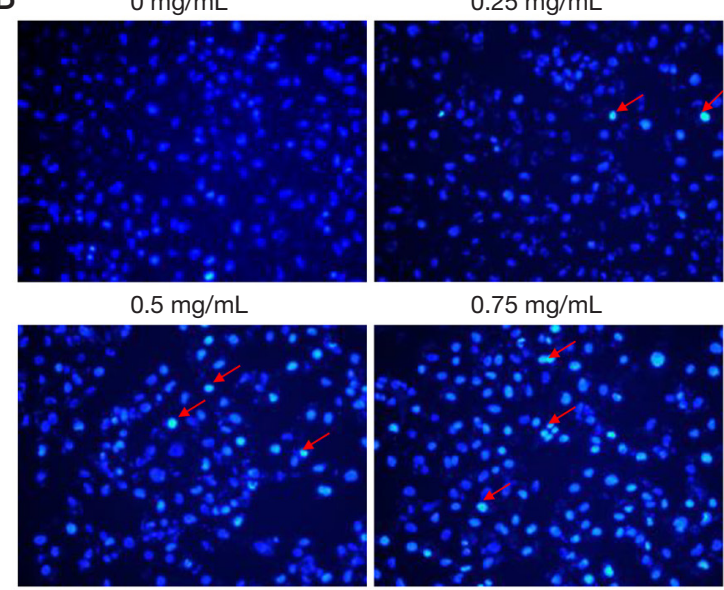

$0.75 \mathrm{mg} / \mathrm{mL}$

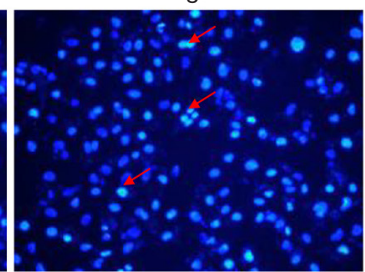

C

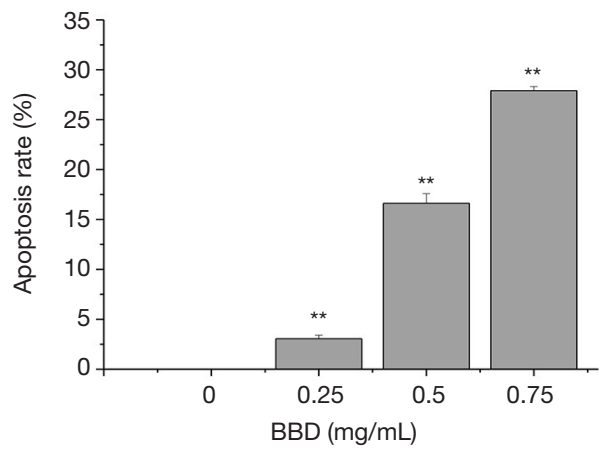

Figure 2 BBD inhibited cells viability and induced apoptosis of HUVECs. (A) HUVEC cells were incubated at different concentrations of BBD for $24 \mathrm{~h}$ and then cell viability was assayed by MTT. (B) HUVECs treated by BBD for $24 \mathrm{~h}$ with different concentrations and then cells apoptosis were detected by Hoechst assay. (C) The data of apoptosis rate were shown as means \pm SD of three independent experiments. * $\mathrm{P}<0.05$ and ${ }^{* *}, \mathrm{P}<0.01$ versus control $(0 \mathrm{mg} / \mathrm{mL})$.
Then the apoptosis rate, the damage repair ability and migration ability of the VEGFA-induced of HUVECs were measured by Hoechst 33258, wound healing assays, MTT and Transwell migration analysis respectively after treated for $24 \mathrm{~h}$ by different concentration BBD. As showed in the Figure 5C,D the apoptosis rate remarkably increased after VEGFA stimulated the cell viability enhancing, and the apoptotic cells are marked with arrowhead. In the Figure 6 , Figure $6 A, B, D, E$ the same trend was observed that the damage repair ability and the migration ability which increased by VEGFA were significantly reduced by BBD in a dose-dependent manner. In the Figure $6 C, F$ BBD tube formation also increased after VEGFA stimulated and significantly inversed by BBD treatment. Last, the level of the target proteins was shown in the Figure 7, BBD downregulated the expression of VEGFA, VEGFR2, MMP2 and MMP9 which were induced to up-regulate by VEGFA.

\section{Discussion}

GC is one of the most common cancers in the world and is the current medical problem for exploration (17). The minority of GC patients is diagnosed at middle-late stage and it is estimated that about less than $30 \%$ of cases of stomach cancer survive for more than 5 years (18). Therefore, it is badly in need of new novel and less toxic agents to increase the 5-year survival rate associated with GC. Over the years, more and more attentions are paid to the antiangiogenesis effect of TCM in cancer treatment (19). Angiogenesis is a tough requirement in the process of promoting the disease progression or wound healing. As tumor progression angiogenesis provides oxygen and nutrients to cancer cells to maintain appropriate conditions for fast growth (20) which makes it crucial to cancer metastasis. Base on that anti-angiogenesis is becoming more and more important on finding a promising strategy for cancer treatment (21). Up to now the development of anti-angiogenesis drugs is primary by blocking the VEGF/ VEGFR signaling pathway to destroy the supply nutrition and oxygen (22). The switches of tumor angiogenesis are turned on by the angiogenic factors such as VEGFs, basic fibroblast growth factors and matrix metalloproteinases secreted by tumor cells or host cells (macrophages). Among 
A
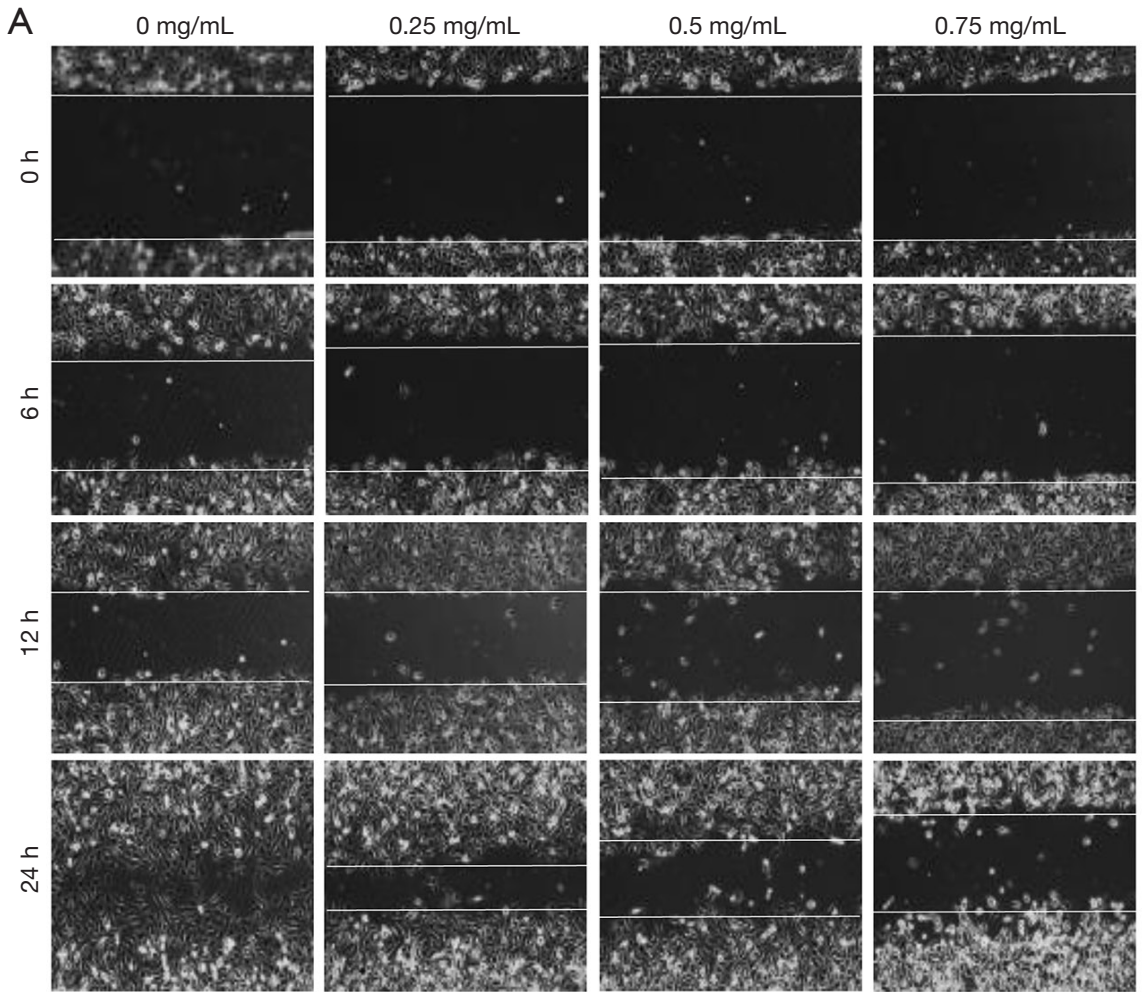

B

$0.25 \mathrm{mg} / \mathrm{mL}$
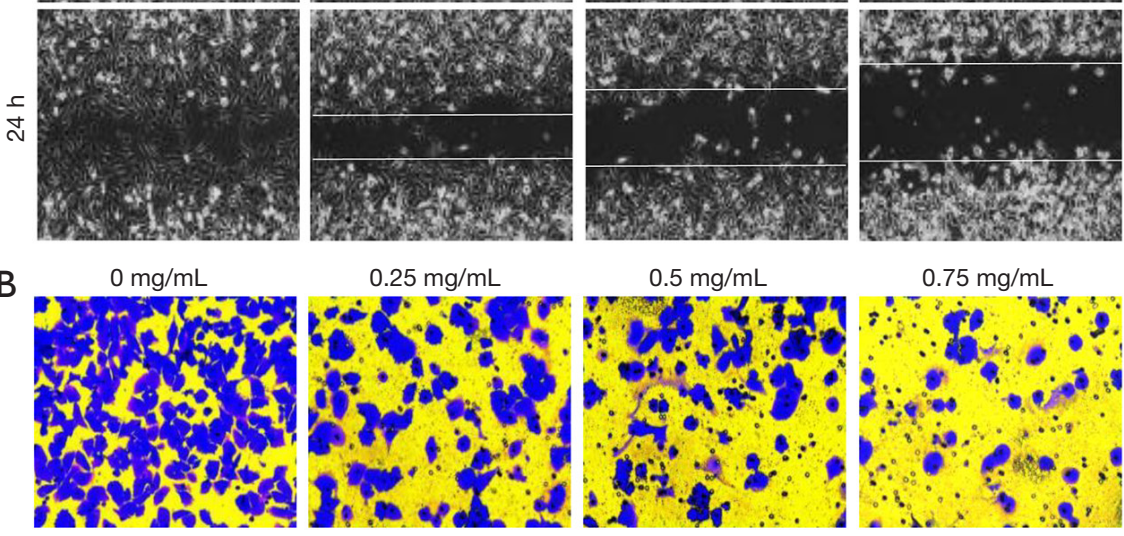

$0.5 \mathrm{mg} / \mathrm{mL}$

$0.75 \mathrm{mg} / \mathrm{mL}$
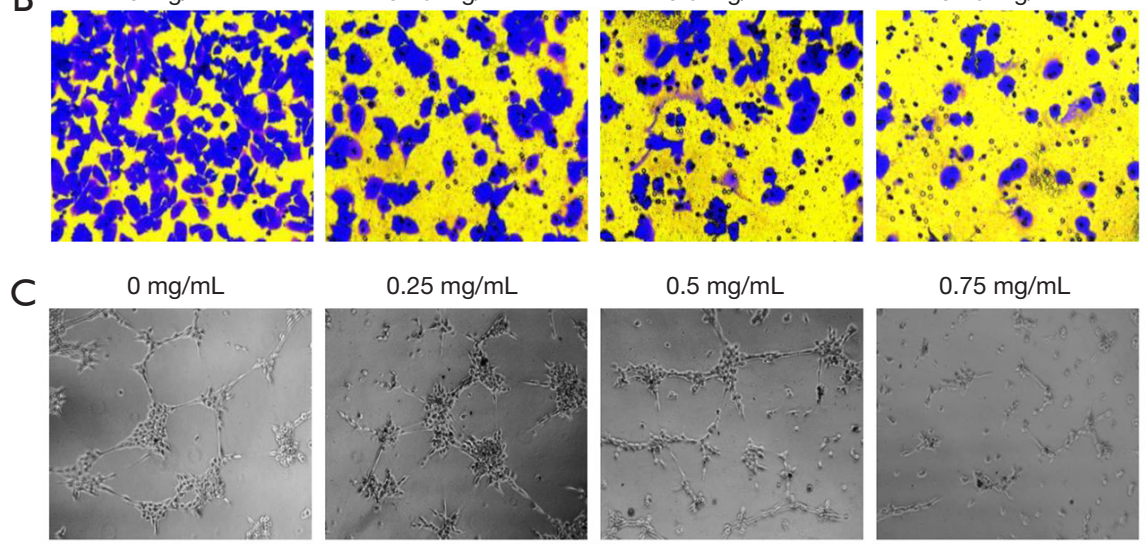

$0.25 \mathrm{mg} / \mathrm{mL}$

$0.5 \mathrm{mg} / \mathrm{mL}$

$0.75 \mathrm{mg} / \mathrm{mL}$
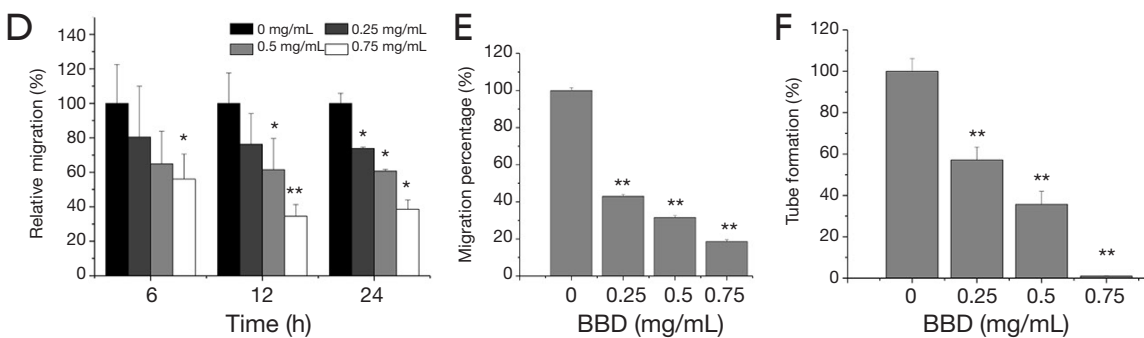

Figure 3 BBD inhibited HUVECs' wound repairing, migration and tube formation. (A) HUVECs' treated by BBD and wound repairing were observed by inverted microscope (photos 100x) at 0, 6, 12 and 24 h. (B) HUVECs' migration was tested by Transwell migration assay at $12 \mathrm{~h}$ after described concentrations of BBD treated and photos observed by inverted microscope (100x). (C) HUVECs were treated by described concentrations BBD for $24 \mathrm{~h}$ and then used to test the angiogenesis ability in vitro. Tube formation was observed at $3 \mathrm{~h}$ by inverted microscope $(100 \times)$. (D-F) Data were shown as means \pm SD from three independent experiments. *, $\mathrm{P}<0.05 ;{ }^{* *}, \mathrm{P}<0.01$, versus control cells $(0 \mathrm{mg} / \mathrm{mL})$. 
A
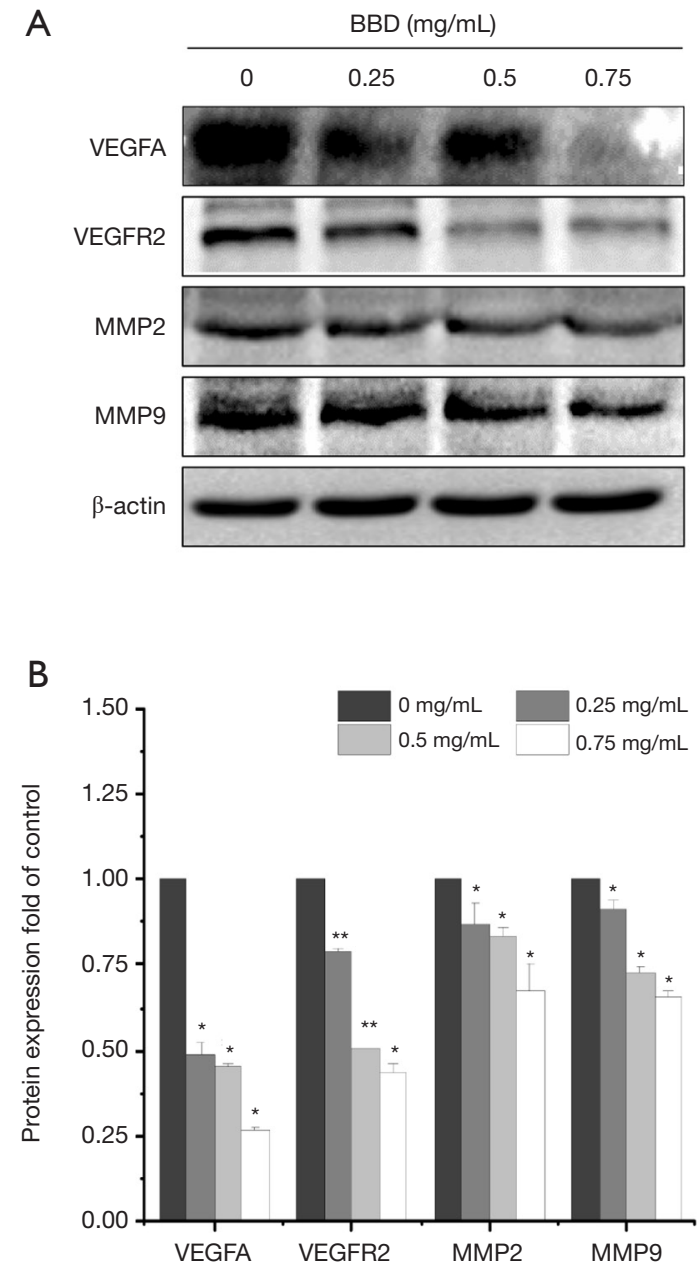

Figure 4 BBD regulated VEGFA, VEGFR2, MMP9 and MMP2 expression levels in HUVECs. (A) HUVECs were treated by BBD for $24 \mathrm{~h}$ and then protein level (VEGFA, VEGFR2, MMP2 and MMP9) was evaluated by western blot assay. (B) Data were normalized to the control cells $(0 \mathrm{mg} / \mathrm{mL})$ and represented as the fold of control. *, $\mathrm{P}<0.05$ and **, $\mathrm{P}<0.01$ versus control cells.

the growth factors associated with angiogenesis, VEGFA is the critical one which can be as a potent inducer of vascular growth. VEGFs need combine with its receptor VEGFR to activate the cascade reaction of numerous intermediate signals in the downstream pathways (23), and eventually promotes proliferation and migration of endothelial cell (24). The transmembrane glycoprotein VEGFR2 is the main signal receptor of VEGFA, mediates the VEGFA associated downstream effect of angiogenesis, including endothelial cell survival, invasion, tube formation and germination (7). According to published reports, VEGFA/VEGFR2 is the most significant ligand/receptor complex in accelerating the survival activity of endothelial cells to format of new blood vessels in the VEGFs system (25). Our previous study has found that HUVECs migration ability was markedly inhibited after BBD intervention (26). This study results provided an experimental evidence that BBD decreased proliferation ability and VEGFA level of tumor GC cell lines. Furtherly, BBD inhibited the HUVECs biological behavior including repair ability, migration ability and angiogenesis ability induced by VEGFA or not. The protein expression also demonstrated that BBD regulated the VEGFA and VEGFR2 levels which are the crucial molecules to trigger a series of reaction for cells angiogenesis. Between tumor cells and endothelial cells the VEGFA was used as inducer to stimulate microenvironment conditions to transduce angiogenesis signals into programmed responses. In present study, BBD inhibited the metastatic and angiogenic ability of HUVECs induced by VEGFA. Current opinion holds that VEGF/VEGFR signaling pathway promotes tumor angiogenesis, growth, invasion and metastasis (27). Inhibiting VEGFA/VEGFR2 signaling pathway is a common strategy for tumor therapy (28). Our study results also confirmed the above opinion that BBD inhibited VEGFA-induced HUVECs growth, cyto behavior and angiogenesis by VEGFA/VEGFR2 signaling pathway.

Some investigations to study the occurrence and development of angiogenesis in tumor, MMP2 and MMP9 can degrade the IV collagen components in the basal membrane and extracellular matrix, remodel the extracellular matrix and promote the mobility of vascular epithelial cells. And then VEGFA induces the proliferation and inhibits apoptosis of vascular epithelial cells. The data from 249 gastric carcinoma tissue samples showed that the level of MMP2 and MMP9 was positive correlation with the levels of VEGF which both were closely correlated with angiogenesis and progression (29). Some reports have indicated that the MMP2 and MMP9 played important roles in the angiogenic switch and stimulated VEGF release which eventually led to tumor angiogenesis (30). Our present study results also showed that BBD downregulated the level of MMP2 and MMP9 induced by VEGFA.

GC is still a common cancer and is an important focus of clinical, epidemiological and transformational research (31). Some studies have shown that the angiogenesis of blood vessels requires the activation of phosphatidylinositol 3-kinase/protein kinase B and 
A

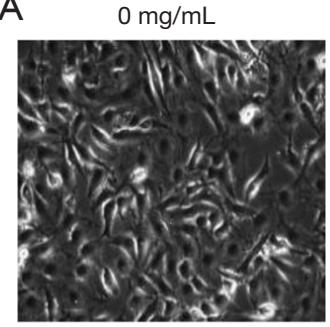

C

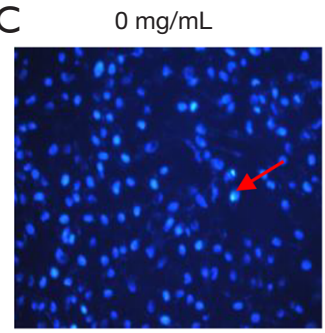

B

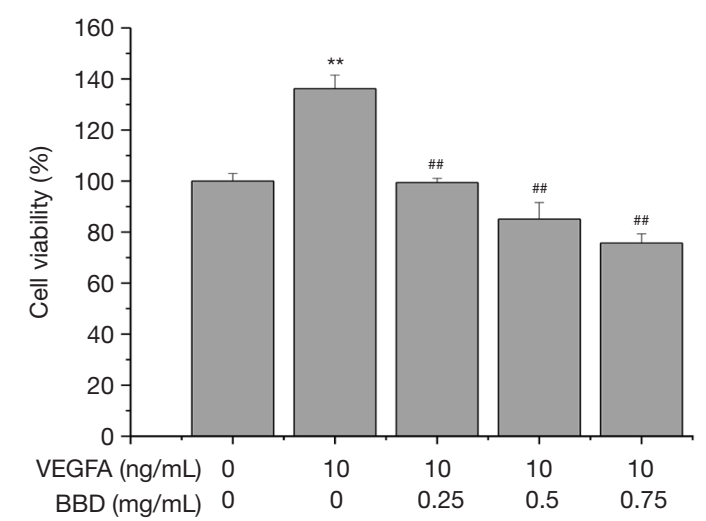

$0.25 \mathrm{mg} / \mathrm{mL}+$ VEGFA

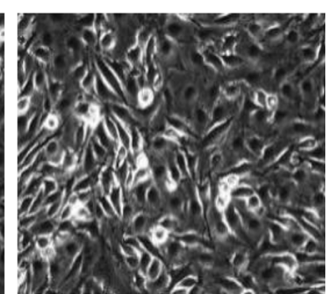

VEGFA
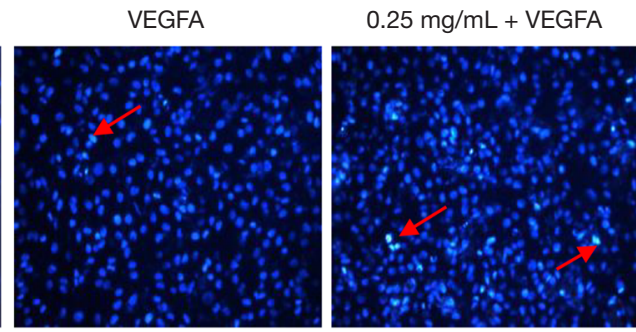

$0.5 \mathrm{mg} / \mathrm{mL}+$ VEGFA

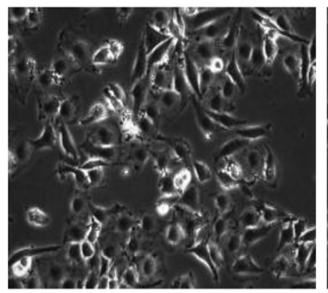

$0.5 \mathrm{mg} / \mathrm{mL}+$ VEGFA

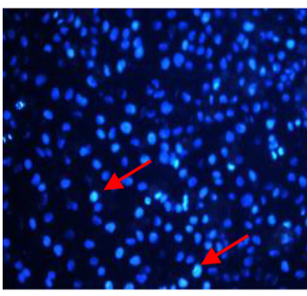

$0.75 \mathrm{mg} / \mathrm{mL}+$ VEGFA

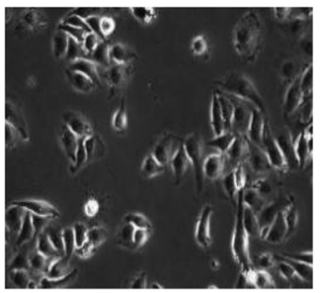

$0.75 \mathrm{mg} / \mathrm{mL}+$ VEGFA

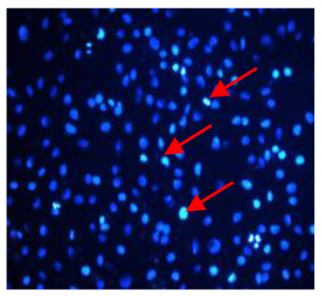

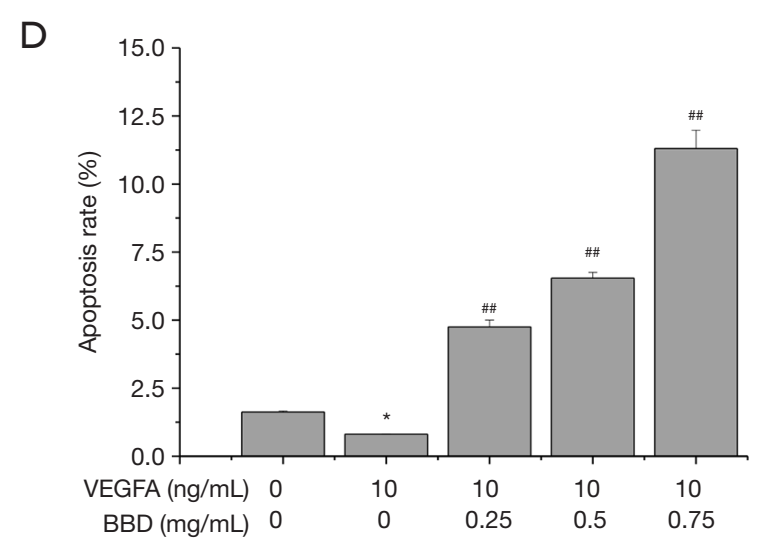

Figure 5 BBD reversed HUVECs' proliferation and apoptosis induced by VEGFA. (A) HUVECs were treated by BBD for 24 h on VEGFAinduced $(10 \mathrm{ng} / \mathrm{mL})$ or non-induced $(0 \mathrm{ng} / \mathrm{mL})$ conditions. Cells morphology was observed by inverted microscope (100x). (B) The proliferation ability of HUVECs were measured by MTT assay. (C) Cells apoptosis was assayed by Hoechst assay and observed by inverted microscope (100x). (D) The data of apoptosis rate were shown as means \pm SD. of three independent experiments. *, $\mathrm{P}<0.05$ and ${ }^{* *}, \mathrm{P}<0.01$ versus control $(0 \mathrm{mg} / \mathrm{mL}),{ }^{*}, \mathrm{P}<0.05$ and ${ }^{\# \#}, \mathrm{P}<0.01$ versus VEGFA.

mitogen-activated protein kinase/extracellular regulated protein kinases signaling pathway (32), the level of the downstream molecular rat sarcoma, phosphorylation of A-rapidly accelerated fibrosarcoma (Raf), B-Raf, C-Raf, methyl ethyl ketone, and Erk1/2 was positive correlation with the levels of VEGFA/VEGFR2 pathway (33). Relevant studies showed that bile acid is the functional component of Bovis and Snake Gall to reduce vascular endothelial cells growth and VEGF secretion $(34,35)$. And the hydrophobic bile acid (LCA) can reduce tube formation (36). What are the essential components of anti-angiogenesis and anti-tumor of BBD is an important question to study in future.

\section{Conclusions}

In this study, results show that BBD inhibits angiogenesis of GC in vitro by regulating VEGFA/VEGFR2 signaling pathway. It provides more helping evidence in future for in vivo experiments as well as clinical treatment. 
A
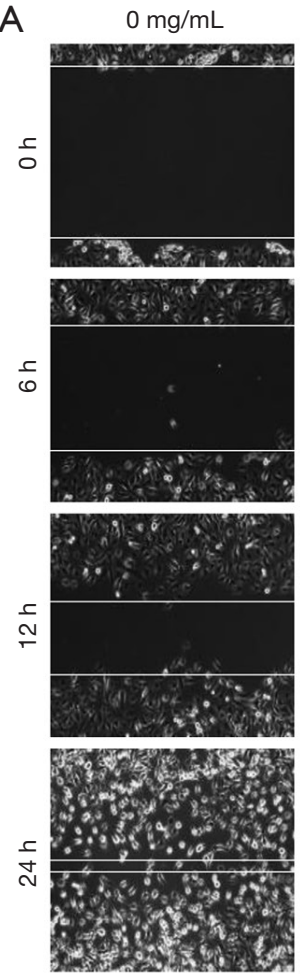

B

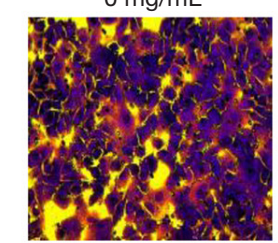

C

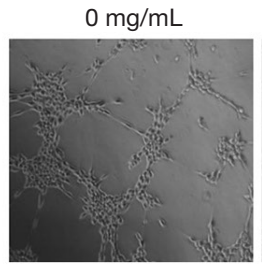

D

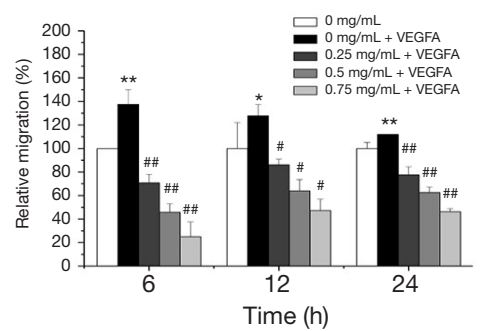

VEGFA

VEGFA

VEGFA
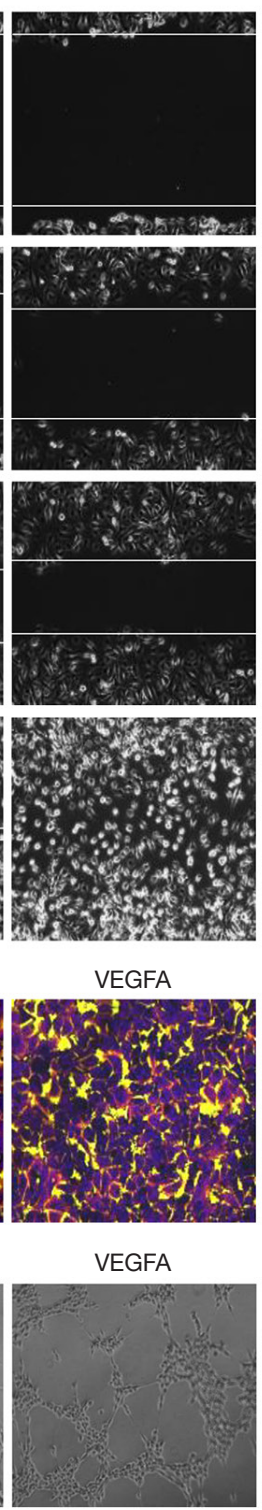

$E$
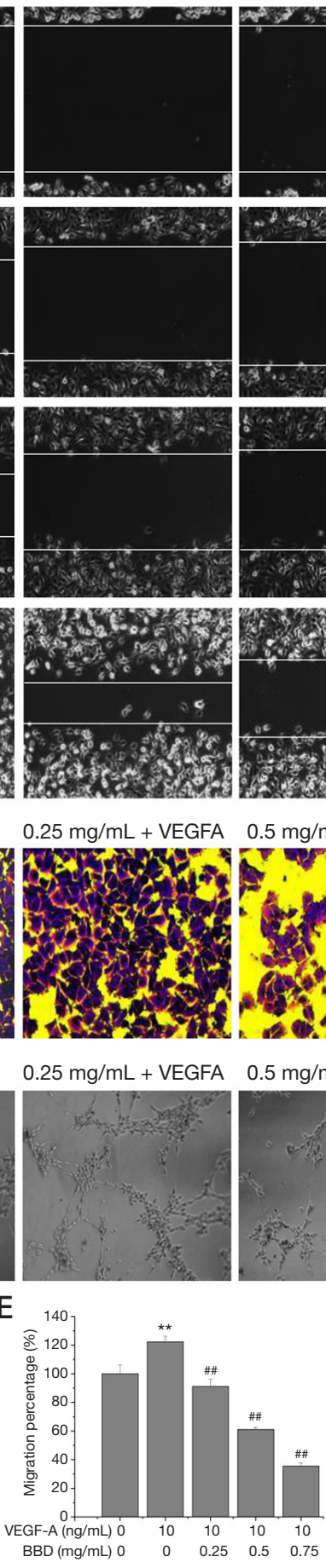

$0.25 \mathrm{mg} / \mathrm{mL}$ + VEGFA $\quad 0.5 \mathrm{mg} / \mathrm{mL}+$ VEGFA $\quad 0.75 \mathrm{mg} / \mathrm{mL}+$ VEGFA
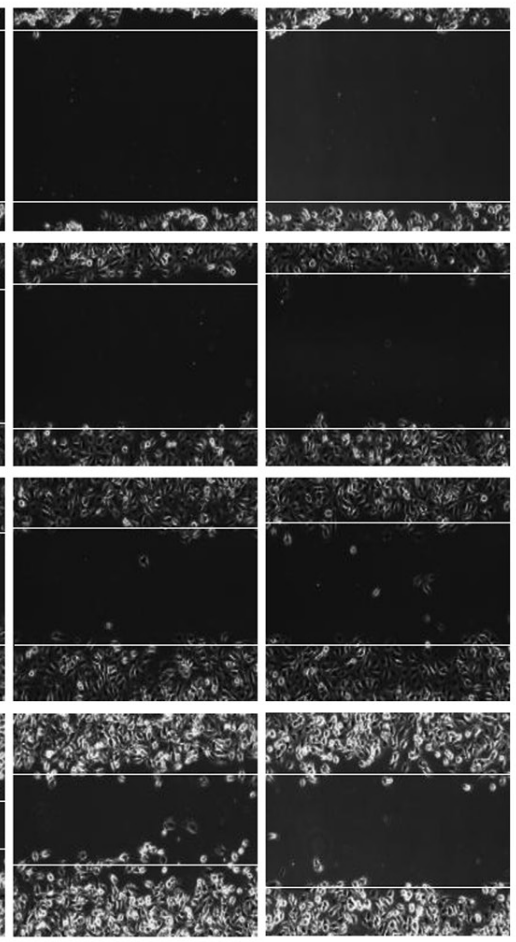

$0.25 \mathrm{mg} / \mathrm{mL}+$ VEGFA $\quad 0.5 \mathrm{mg} / \mathrm{mL}+$ VEGFA $\quad 0.75 \mathrm{mg} / \mathrm{mL}+$ VEGFA

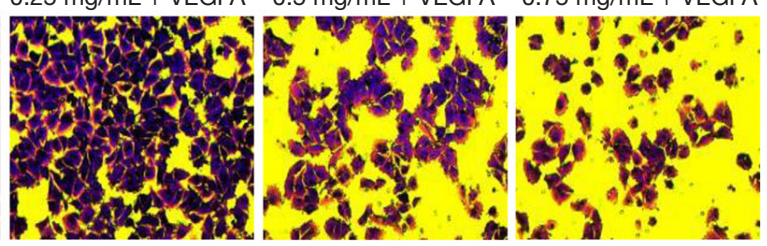

$0.25 \mathrm{mg} / \mathrm{mL}+$ VEGFA $\quad 0.5 \mathrm{mg} / \mathrm{mL}+$ VEGFA $\quad 0.75 \mathrm{mg} / \mathrm{mL}+$ VEGFA
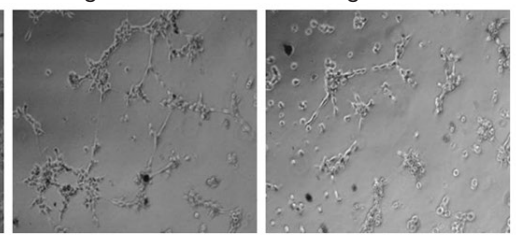

$\mathrm{F}$

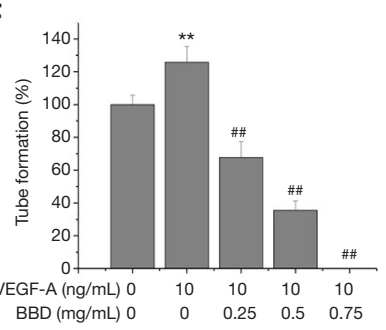

Figure 6 BBD inhibited wound repairing, migration and tube formation of HUVECs induced by VEGFA. (A) HUVECs were treated by BBD for $24 \mathrm{~h}$ on VEGFA-induced $(10 \mathrm{ng} / \mathrm{mL})$ or non-induced $(0 \mathrm{ng} / \mathrm{mL})$ conditions. Wound repairing was observed by inverted microscope (100x) at 0, 6, 12 and 24 h. (B) On above experiment (A) conditions, HUVECs' migration was tested by Transwell migration assay (12 h). (C) On above experiment conditions, tube formation assay was used to test the angiogenesis ability of HUVEC in vitro. Tube formation was observed by inverted microscope (100x). (D-F) Data were shown as means \pm SD from three independent experiments. *, $\mathrm{P}<0.05$ and **, $\mathrm{P}<0.01$, versus control cells $(0 \mathrm{mg} / \mathrm{mL}), \stackrel{ }{\#}, \mathrm{P}<0.05$ and ${ }^{\# \#}, \mathrm{P}<0.01$ versus control (VEGFA). 

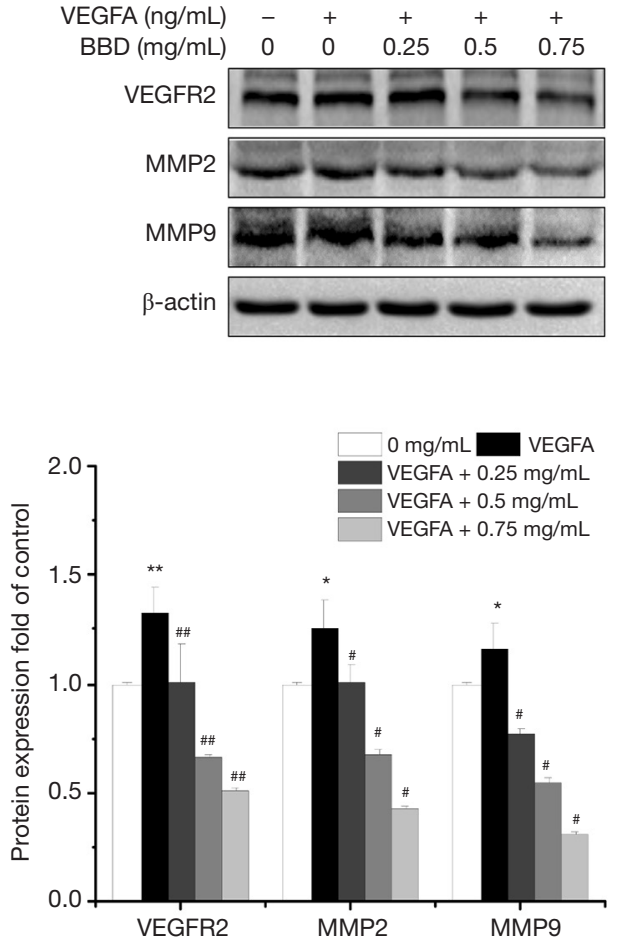

Figure 7 BBD regulated VEGFR2, MMP2 and MMP9 levels of HUVECs induced by VEGFA. (A) HUVECs were treated by BBD $(0,0.25,0.5,0.75 \mathrm{mg} / \mathrm{mL})$ for $24 \mathrm{~h}$ on VEGFA-induced $(10 \mathrm{ng} / \mathrm{mL})$ or non-induced $(0 \mathrm{ng} / \mathrm{mL})$ conditions. Western blot detected the level of VEGFR2, MMP2 and MMP9. (B) Data were normalized to the control cells $(0 \mathrm{mg} / \mathrm{mL})$ and represented as the fold of control. *, $\mathrm{P}<0.05$ and $^{* *}, \mathrm{P}<0.01$ versus control cells,,, $\mathrm{P}<0.05$ and ${ }^{\# \#}, \mathrm{P}<0.01$ versus control (VEGFA).

\section{Acknowledgments}

Thank Xiamen Traditional Chinese Medicine Factory Co., Ltd. for providing BBD.

Funding: This work was supported by the Natural Science Foundation of Fujian Province, China (No. 2019J01355).

\section{Footnote}

Reporting Checklist: The authors have completed the MDAR checklist. Available at http://dx.doi.org/10.21037/tcr-202559

Data Sharing Statement: Available at http://dx.doi. org/10.21037/tcr-20-2559

Conflicts of Interest: All authors have completed the ICMJE uniform disclosure form (available at http://dx.doi. org/10.21037/tcr-20-2559). The authors have no conflicts of interest to declare.

Ethical Statement: The authors are accountable for all aspects of the work in ensuring that questions related to the accuracy or integrity of any part of the work are appropriately investigated and resolved. This study was conducted in vitro and did not involve any animals or clinical patients, so IRB approval is not applicable.

Open Access Statement: This is an Open Access article distributed in accordance with the Creative Commons Attribution-NonCommercial-NoDerivs 4.0 International License (CC BY-NC-ND 4.0), which permits the noncommercial replication and distribution of the article with the strict proviso that no changes or edits are made and the original work is properly cited (including links to both the formal publication through the relevant DOI and the license). See: https://creativecommons.org/licenses/by-nc-nd/4.0/.

\section{References}

1. Li Q, Kan X, Yin J, et al. Chamaejasmine B Induces the Anergy of Vascular Endothelial Cells to VEGFA Proangiogenic Signal by Autophagic Regulation of VEGFR2 in Breast Cancer. Front Pharmacol 2018;8:963.

2. Cunningham D, Allum WH, Stenning SP, et al. Perioperative chemotherapy versus surgery alone for resectable gastroesophageal cancer. $\mathrm{N}$ Engl J Med 2006;355:11-20.

3. Viallard C, Larrivée B. Tumor angiogenesis and vascular normalization: alternative therapeutic targets. Angiogenesis 2017;20:409-26.

4. Rudno-Rudzińska J, Kielan W, Frejlich E, et al. A review on Eph/ephrin, angiogenesis and lymphangiogenesis in gastric, colorectal and pancreatic cancers. Chin J Cancer Res 2017;29:303-12.

5. Costache MI, Ioana $M$, Iordache $S$, et al. VEGF Expression in Pancreatic Cancer and Other Malignancies: A Review of the Literature. Rom J Intern Med 2015;53:199-208.

6. Ferrara N, Gerber HP, LeCouter J. The biology of VEGF and its receptors. Nat Med 2003;9:669-76.

7. Zhang C, Wang N, Tan HY, et al. Targeting VEGF/ VEGFRs Pathway in the Antiangiogenic Treatment of Human Cancers by Traditional Chinese Medicine. Integr Cancer Ther 2018;17:582-601. 
8. Ji YN, Wang Q, Li Y, et al. Prognostic value of vascular endothelial growth factor A expression in gastric cancer: a meta-analysis. Tumour Biol 2014;35:2787-93.

9. Song LB, Gao S, Zhang AQ, et al. Babaodan Capsule combined with Qingyi Huaji Formula in advanced pancreatic cancer-a feasibility study. Chin J Integr Med 2017;23:937-42.

10. Liang L, Yang X, Yu Y, et al. Babao Dan attenuates hepatic fibrosis by inhibiting hepatic stellate cells activation and proliferation via TLR4 signaling pathway. Oncotarget 2016;7:82554-66.

11. Ke Y, Zhao HY. Research progress of clinical application of Babao Dan. Chinese Traditional Patent Medicine 2017;39:386-89.

12. Gong W, Liu L, Li M, et al. Evaluation of antiviral efficacy of Chinese traditional medicine Babao Dan in rabbits infected with hepatitis E virus. J Gen Virol 2018;99:1036-43.

13. Li HL, Cheng Y. Effect of Babaodan monotherapy and combined with cisplatin on the expression of cells A549 and SPCA-1 in lung adenocarcinoma. Chin J Clinicians (Electronic Edition) 2017;11:67-71.

14. Zhou Z, Lin JH. Proliferation inhibition and apoptosis induction of Ba-Bao-Dan (BBD) in human osteosarcoma U-2OS cells. Chin J Tradit Med Traumatol Orthop 2006;(S2):93-5.

15. Shang H, Cao ZY, Zhao JY, et al. Babao Dan induces gastric cancer cell apoptosis via regulating MAPK and NF$\kappa \mathrm{B}$ signaling pathways. J Int Med Res 2019;47:5106-19.

16. Liu J, Chen Y, Cao Z, et al. Babao Dan inhibits the migration and invasion of gastric cancer cells by suppressing epithelial-mesenchymal transition through the TGF- $\beta /$ Smad pathway. J Int Med Res 2020;48:300060520925598.

17. Fu DG. Epigenetic alterations in gastric cancer (Review). Mol Med Rep 2015;12:3223-30.

18. den Hoed CM, Kuipers EJ. Gastric Cancer: How Can We Reduce the Incidence of this Disease? Curr Gastroenterol Rep 2016;18:34.

19. Chao J, Dai Y, Verpoorte R, et al. Major achievements of evidence-based traditional Chinese medicine in treating major diseases. Biochem Pharmacol 2017;139:94-104.

20. Pezzella F, Harris AL, Tavassoli M, et al. Blood vessels and cancer much more than just angiogenesis. Cell Death Discov 2015;1:15064.

21. Cao Z, Lin W, Huang Z, et al. Jiedu Xiaozheng Yin, a Chinese herbal formula, inhibits tumor angiogenesis via downregulation of VEGF-A and VEGFR-2 expression in vivo and in vitro. Oncol Rep 2013;29:1080-6.

22. Ramjiawan RR, Griffioen AW, Duda DG. Antiangiogenesis for cancer revisited: Is there a role for combinations with immunotherapy? Angiogenesis 2017;20:185-204.

23. Savage AM, Kurusamy S, Chen Y, et al. tmem33 is essential for VEGF-mediated endothelial calcium oscillations and angiogenesis. Nat Commun 2019;10:732.

24. Hu S, Liu Y, You T, et al. Semaphorin 7A Promotes VEGFA/VEGFR2-Mediated Angiogenesis and Intraplaque Neovascularization in ApoE-/- Mice. Front Physiol 2018;9:1718.

25. Abhinand CS, Raju R, Soumya SJ, et al. VEGF-A/ VEGFR2 signaling network in endothelial cells relevant to angiogenesis. J Cell Commun Signal 2016;10:347-54.

26. Guan JH, Jin YY, Zhuang QC, et al. Effects of Baobao Dan on proliferation and migration of human umbilical vein endothelial cells. Fujian Zhongyi Yao 2018;49:64-6.

27. Sharma K, Patidar K, Ali MA, et al. Structure-Based Virtual Screening for the Identification of High Affinity Compounds as Potent VEGFR2 Inhibitors for the Treatment of Renal Cell Carcinoma. Curr Top Med Chem 2018;18:2174-85.

28. Estrada CC, Maldonado A, Mallipattu SK. Therapeutic Inhibition of VEGF Signaling and Associated Nephrotoxicities. J Am Soc Nephrol 2019;30:187-200.

29. Zheng H, Takahashi H, Murai Y. Expressions of MMP2, MMP9 and VEGF are closely linked to growth, invasion, metastasis and angiogenesis of gastric carcinoma. Anticancer Res 2006;26:3579-83.

30. Rundhaug JE. Matrix metalloproteinases and angiogenesis. J Cell Mol Med 2005;9:267-85.

31. Karimi P, Islami F, Anandasabapathy S, et al. Gastric cancer: descriptive epidemiology, risk factors, screening, and prevention. Cancer Epidemiol Biomarkers Prev 2014;23:700-13.

32. Sadremomtaz A, Mansouri K, Alemzadeh G, et al. Dual blockade of VEGFR1 and VEGFR2 by a novel peptide abrogates VEGF-driven angiogenesis, tumor growth, and metastasis through PI3K/AKT and MAPK/ ERK1/2 pathway. Biochim Biophys Acta Gen Subj 2018;1862:2688-700.

33. Wang Y, Zhang F, Wang J, et al. LncRNA LOC100132354 promotes angiogenesis through VEGFA/VEGFR2 signaling pathway in lung adenocarcinoma. Cancer Manag Res 2018;10:4257-66.

34. Li Y, Yu J, Zhao Y, et al. UHPLC-Q-TOF-MS in analyzing chemical constituents of traditional Chinese 
herbal preparation Babao Dan. Academic Journal of Second Military Medical University 2016,37:1548-54.

35. Xia S. Study on the relationship between intrahepatic cholestasis of pregnancy and vascular endothelial growth factor. Third Military Medical University. 2002.

Cite this article as: Guan JH, Cao ZY, Guan B, Wei LH, Peng J, Chen YQ, Sferra TJ, Sankararaman S, Zhan ZX, Lin JM. Effect of Babao Dan on angiogenesis of gastric cancer in vitro by regulating VEGFA/VEGFR2 signaling pathway. Transl Cancer Res 2021;10(2):953-965. doi: 10.21037/tcr-20-2559
36. Kundu S, Bansal S, Muthukumarasamy KM, et al. Deciphering the role of hydrophobic and hydrophilic bile acids in angiogenesis using in vitro and in vivo model systems. Medchemcomm 2017;8:2248-57. 


\section{Supplementary}
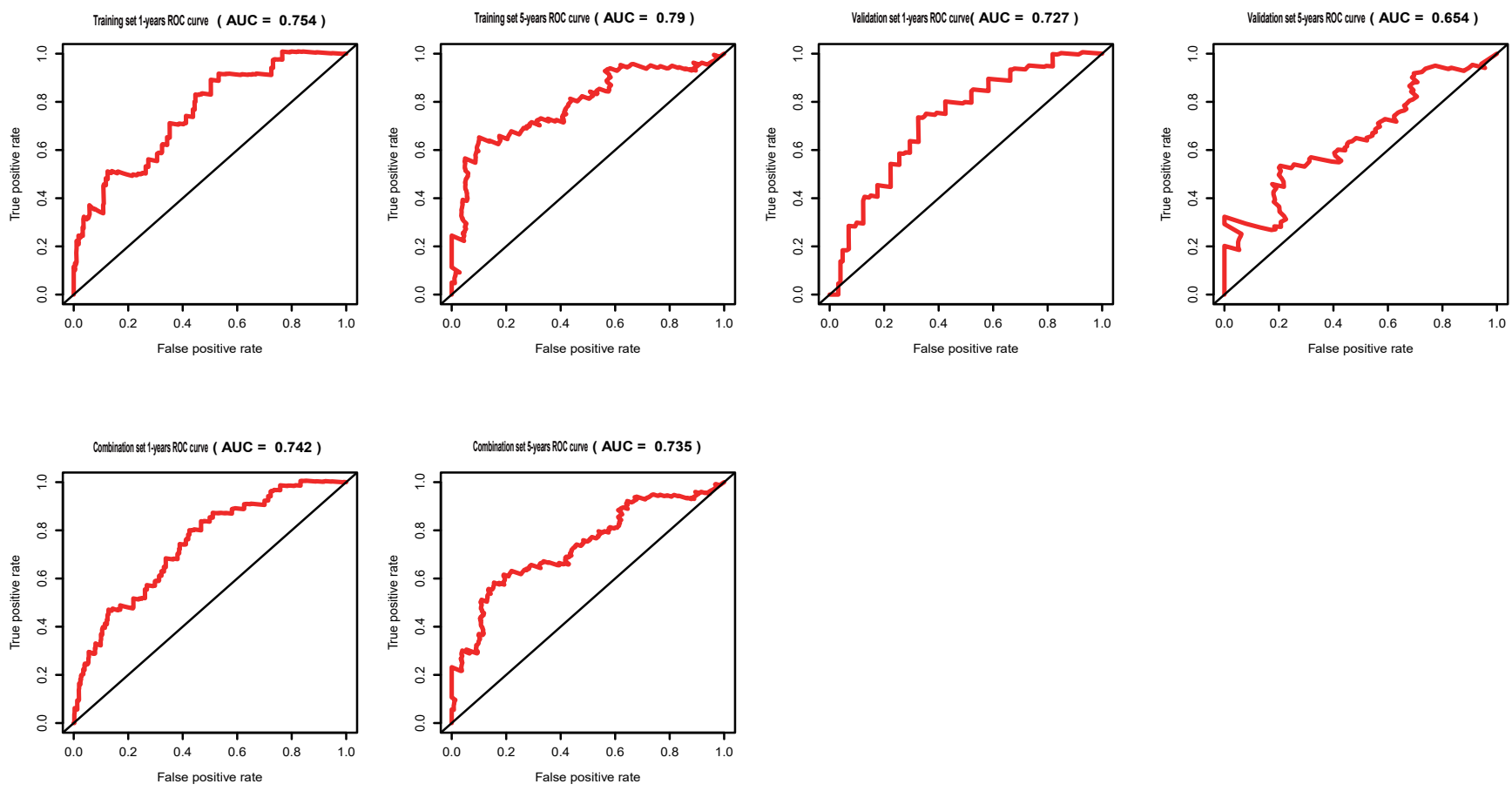

Figure S1 1- and 5-year time-dependent ROC analysis of the lncRNA risk signature in the training, validation, and combination set.
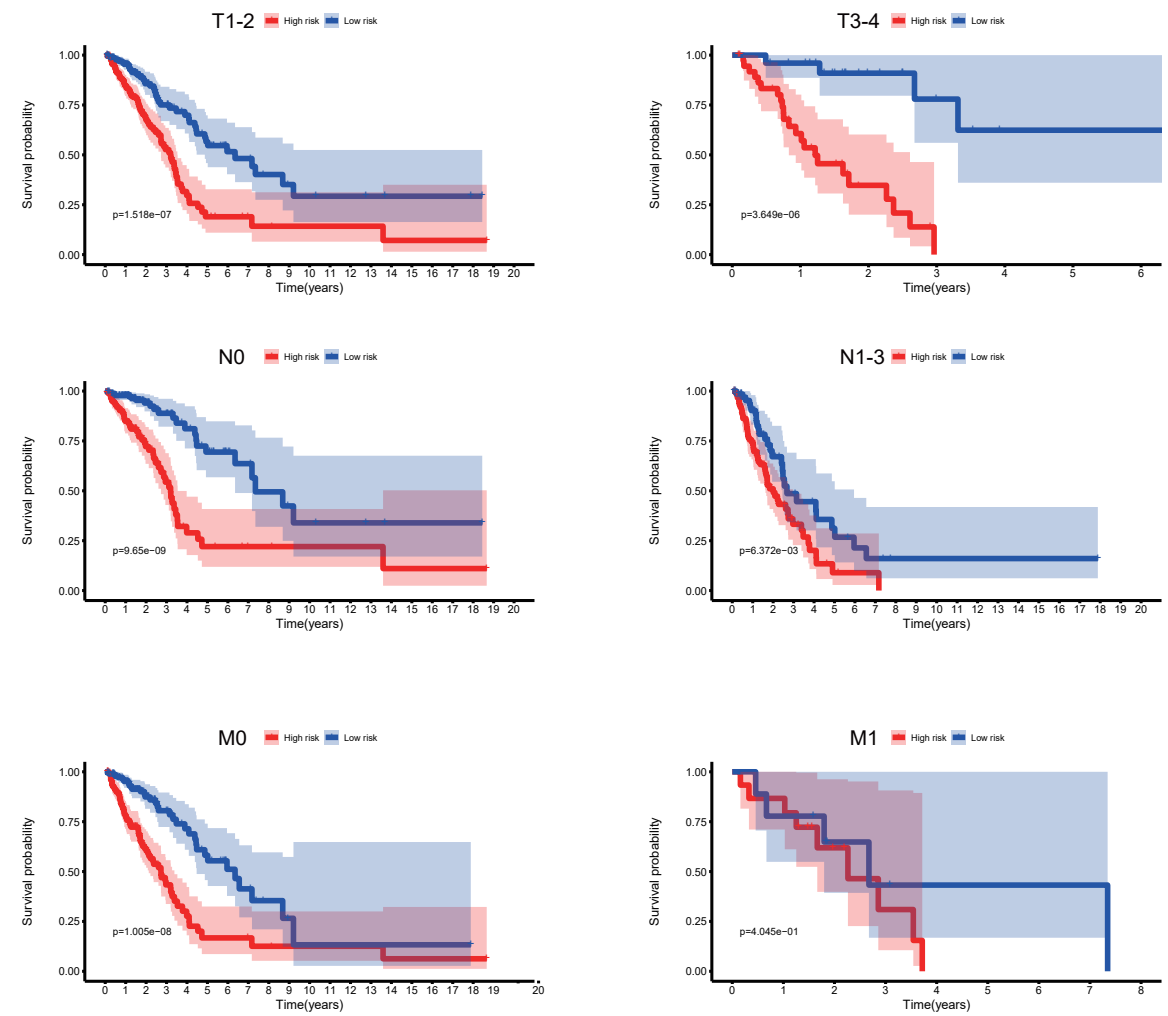

Figure S2 The difference in survival curves between the high- and low-risk group stratified by TNM stage. 
Table S1 The comparison analysis between the training set and validation set

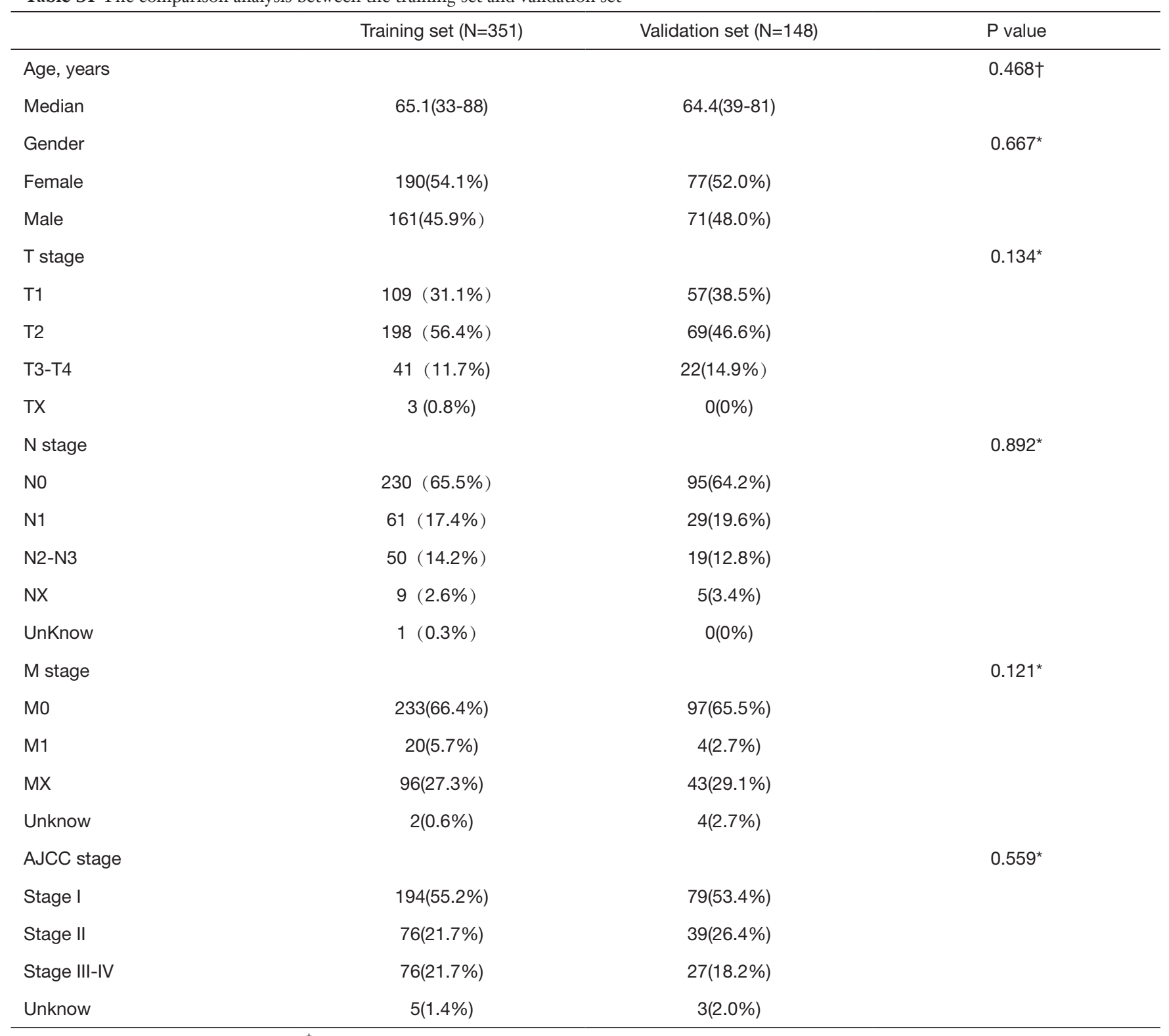

* chi-square or Fisher's exact test. ${ }^{\dagger}$ student's $t$-test. 